\title{
Shelf life determination of durian (Durio zibethinus) paste and pulp upon high- pressure processing
}

\author{
Tan, P.F., Ng, S.K., Tan, T.B., Chong, G.H. and *Tan, C.P. \\ Department of Food Technology, Faculty of Food Science and Technology, Universiti Putra Malaysia, \\ 43400 UPM, Serdang, Selangor, Malaysia
}

\begin{abstract}
Article history:
Received: 21 July 2018

Received in revised form: 14

September 2018

Accepted: 18 September 2018

Available Online: 19

November 2018
\end{abstract}

Keywords:

High-pressure processing,

Durian,

Shelf life,

Microbiological count,

Polygalacturonase,

Pectin methyl esterase

DOI:

https://doi.org/10.26656/fr.2017.3(3).215

\begin{abstract}
Globally, there has been an increase in demand for durian. Therefore, it is important to extend the shelf life and at the same time, maintain the quality of durian. This study investigated the effect of high-pressure processing (HPP) on the shelf life of durian paste and pulp. Specifically, HPP treatments of $500 \mathrm{MPa}$ for $5 \mathrm{~min}$ on nylon- and skin filmpacked durian pulp, and $600 \mathrm{MPa}$ for $5 \mathrm{~min}$ on nylon-packed durian paste were applied. It was found that throughout the 56-day storage period, the total soluble solids (TSS), pH and titratable acidity of durian paste and pulp showed no significant changes ( $p>0.05)$. The colour ( $\mathrm{L}^{*}$ values) of nylon-packed untreated durian pulp showed no significant changes $(p>0.05)$, while the untreated durian paste and skin film-packed durian pulp showed significant changes $(\mathrm{p}<0.05)$. As for chroma values, it showed no significant changes $(p>0.05)$ throughout the storage period. The microbial levels of all the highpressure (HP)-treated durian samples remained below the detection limit till the end of the storage study. HP-treated durian samples showed lower enzymatic (polygalacturonase and pectin methyl esterase) activities compared to untreated sample throughout the storage period. Sensory evaluation showed no significant difference $(p>0.05)$ between untreated and HP-treated samples. In summary, HPP effectively maintained the overall quality of durian for a minimum of 56 days.
\end{abstract}

\section{Introduction}

Durian (Durio zibethinus), of the Bombacacaea family, is a seasonal tropical fruit that is widely cultivated in Southeast Asia, particularly in tropical countries such as Malaysia, Indonesia and Thailand. Dubbed the 'King of Fruits', durian is well-known due to its unique aroma and taste. Moreover, durian is reported to have many health benefits, such as containing many bioactive and antioxidative compounds (Arancibia-Avila et al., 2008), and being a good source of protein (Gorinstein et al., 2011). The uniqueness of durian draws the interest of both Asian and non-Asians, and this led to the increasing demand for durian in both the local and international markets in the past decade (Ho and Bhat, 2015). During high season, there would be an abundance of durian in the market. This results in an oversupply of durian which would eventually reduce the high price of durian significantly (Wasnin et al., 2014). Generally, durian is harvested when it is matured, and consumed fresh. Durian is reported to have a limited shelf life of 34 days (Pauziah et al., 1992). Furthermore, consumers nowadays are being more selective and look beyond the aroma, taste and overall appearance of a fruit. In addition to the aforementioned sensorial qualities, consumers are also looking for the freshest fruits with the highest nutritional values. Therefore, a better alternative technology is required to preserve fruits efficiently in order to deliver good quality products to consumers.

High-pressure processing (HPP) or high hydrostatic processing (HHP) is a non-thermal processing method used in the industry for preservation purposes. HPP is a potential alternative method to the heat- and chemicalbased methods commonly applied in the processing of fruits. However, its application on fruits, especially fresh cut fruits and tropical fruits, has not been getting much attention (Boynton et al., 2002). Previously, there were studies on the use of HPP on products such as mango nectars (Liu et al., 2014), Lonicera caerulea berry (Liu et al., 2016), Granny Smith apple purée product (Landl et al., 2010), and cabbage kimchi (Park et al., 2017).

Packaging materials with high flexibility to withstand high-pressure, high oxygen barrier and sealability properties are required for HPP. In the food industry, nylon is widely used due to its flexibility and flavour retention properties (Ammala, 2011). 
Meanwhile, skin film is an emerging packaging material that can be used for HPP (Bekele, 1990). It is very highly preferred by manufacturers and consumers due to its higher transparency that could provide high aesthetic values to the packaged products.

Studies characterizing the efficacy and impact of HPP on tropical fruits are relatively limited. Amongst the various tropical fruits, preservation of durian using HPP is not well elaborated, especially on a commercial scale using different packaging materials. Thus, this study aimed to examine the shelf life characteristics of HPtreated durian packed using different packaging materials i.e. nylon and skin films. Proper packaging coupled with HPP could provide a solution to the seasonal supply issues faced by the market, while maintaining the high quality of the durian.

\section{Materials and methods}

\subsection{Materials}

All chemicals used were of analytical grade. Media i.e. potato dextrose agar (PDA), MacConkey, eosinmethylene blue (EMB) and plate count agar (PCA) were purchased from Merck (Darmstadt, Germany). Peptone was purchased from Becton (Dickinson and Co., Sparks, MD, USA). Other materials used in this study include polygalacturonic acid and monogalactunoric acid (Sigma -Aldrich, MO, USA), sodium acetate (Merck, Darmstadt, Germany), 2-cyanoacetamide, pectin and pure anhydrous citric acid (Fisher Scientific, Waltham, USA).

\subsection{Preparation of durian paste and durian pulp}

Durian paste is a form of collected flesh that was detached from its seeds and blended and packed into a 2 $\mathrm{kg}$ commercial nylon packaging. Meanwhile, durian pulp refers to the flesh in its original aril form. Durian pulp was packed using two types of packaging; commercial nylon pack and skin film packaging (Multivac, Wolfertschwenden, Germany). Both types of packaging carried $300 \pm 10 \mathrm{~g}$ of durian pulp. The packaging and processing of durian products were all completed in a factory located in Perak, Malaysia. A HPP unit (Hiperbaric 55, Burgos, Spain) was used to process the durian, with water as the pressure medium in the treatment chamber. HPP parameters of $600 \mathrm{MPa}$ for 5 mins for durian paste, and $500 \mathrm{MPa}$ for 5 mins for durian pulp was used in this study. All processed durian paste and pulp were kept at $-18^{\circ} \mathrm{C}$ until further analysis. The quality of the durian paste and pulp was evaluated every 7 days throughout a 56-day storage period.

\subsection{Total soluble solids (TSS)}

Durian paste and pulp were mixed homogenously with distilled water (1:2) and filtered through Whatman No.1 filter paper (Whatman, England, UK). Next, filtered sample was subjected to TSS measurement using refractometer (Atago Co., Ltd, Tokyo, Japan). TSS value was obtained by multiplying with 3 to get a final TSS (\%) value. A total of six measurements were taken at $20^{\circ}$ $\mathrm{C}$ every 7 days throughout the 56-day storage period.

\section{$2.4 \mathrm{pH}$ and titratable acidity}

The quantification of $\mathrm{pH}$ and titratable acidity in durian paste and pulp were carried according to the method of Voon et al. (2006). Briefly, the durian paste and pulp were homogenised with distilled water $(1: 10 \mathrm{w} /$ v) for $1 \mathrm{~min}$ and subjected to $\mathrm{pH}$ measurement by a $\mathrm{pH}$ meter (Sartorius, Göttingen, Germany).

Consequently, the above mentioned mixture was titrated against $0.1 \mathrm{~N} \mathrm{NaOH}$ solutions to the end point of $\mathrm{pH}$ 8.1. The value of titratable acidity was presented as $\mathrm{g}$ malic acid/ $100 \mathrm{~g}$ wet weight using the following formula: $\%$ acid $=\frac{\mathrm{NaOH} \text { used }(\mathrm{mL}) \times \text { molarity of } \mathrm{NaOH} \text { used } \times(\text { miliequivalent factor }) \times 100}{\text { Amount of sample used }(\mathrm{g})}$

where a miliequivalent factor of 0.067 was used, with the assumption that malic acid is the predominant acid.

\subsection{Colour}

The colour of durian paste and pulp was measured using a chromameter (CR-410, Konica Minolta, INC, Tokyo, Japan). The CIELAB parameters of $\mathrm{L}^{*}$ (lightness), $\mathrm{a}^{*}(+\mathrm{a}=\mathrm{red},-\mathrm{a}=$ green $)$ and $(+\mathrm{b}=$ yellow, $b=b l u e)$ were taken. The colour changes was then presented as the hue angle $(\theta)=\tan ^{-1}(\mathrm{~b} / \mathrm{a})$ and chroma $\left(a^{2}+b^{2}\right)^{1 / 2}$.

\subsection{Microbiological analysis}

Microbial analysis of total plate count, coliform, Escherichia coli, yeast and moulds, and psychrophilic bacterial counts was performed on durian paste and pulp during the 56-day storage period. Media used for the analysis was prepared by autoclaving them at $121^{\circ} \mathrm{C}$ for 15 mins before usage. Durian sample ( $25 \mathrm{~g})$ was added with $225 \mathrm{~mL}$ sterilised peptone solution $(0.1 \% \mathrm{w} / \mathrm{v})$ and homogenised using a stomacher for $60 \mathrm{~s}$. Next, serial dilutions was carried out using peptone solution $(0.1 \%$ w/v) prior to plating. Following the standard spread plate procedure, $0.1 \mathrm{~mL}$ of aliquots from each dilution was plated. Determinations of total plate count and psychrophilic counts on plate count agar, coliform bacterial counts on MacConkey agar, E. coli bacterial counts on eosin methylene blue (EMB), and yeast and moulds bacterial counts on potato dextrose agar were performed. The agar plates were incubated at $35 \pm 2^{\circ} \mathrm{C}$ for 48 hours for total plate counts, $4 \pm 2^{\circ} \mathrm{C}$ for 10 days for 
psychrophilic bacterial count, and $25 \pm 2{ }^{\circ} \mathrm{C}$ for 5 days for yeasts and mould counts.

\subsection{Polygalacturonase (PG) analysis}

\subsubsection{Crude enzyme extraction}

Extraction of crude enzyme polygalacturonase (PG) was conducted according to the methods of Terefe et al. (2009) and Amid et al. (2015). First, durian samples and $1.2 \mathrm{M} \mathrm{NaCl}$ solution, $\mathrm{pH} 6.0(1: 6 \mathrm{w} / \mathrm{v})$ were mixed thoroughly for $30 \mathrm{mins}$ in ice. Next, the homogenised mixture was centrifuged at $15,000 \times g$ for 30 mins. Then, the supernatant was collected and filtered using Whatman No. 1 filter paper. The collected solution was used as crude enzyme in PG activity measurement.

\subsubsection{Polygalacturonase analysis}

Polygalacturonase (PG) assay was conducted by referring to the method of Terefe et al. (2009). Analysis of PG activity in durian was based on the formation of reducing sugar as a result of PG-catalysed hydrolysed polygalacturonic acid at $35^{\circ} \mathrm{C}$, and measured using a Cary 60 UV-Vis spectrophotometer (Agilent Technologies, Santa Clara, CA, USA). To perform PGassay, reaction mixture was prepared in the proportion of $100 \mu \mathrm{l}$ crude extract, $300 \mu \mathrm{l}$ of $0.3 \% \quad(\mathrm{w} / \mathrm{v})$ polygalacturonic acid (Sigma-Aldrich, USA) in $40 \mathrm{mM}$ sodium acetate buffer ( $\mathrm{pH} 4.4)$. The reaction mixture was then incubated at $35^{\circ} \mathrm{C}$ for 10 mins. Instantly after 10 mins, borate solution $(\mathrm{pH}=9.0,0.1 \mathrm{M})$ and $400 \mu 1$ of $0.1 \%$ cynoacetamide solution were added into the mixture in order to stop the reaction. After that, the mixture was incubated again at $100^{\circ} \mathrm{C}$ for 10 mins. The incubated mixture was then cooled down in ice-water before being subjected to spectrophotometry measurement. Spectrophotometric reading was taken at room temperature $\left(25^{\circ} \mathrm{C}\right)$, with the absorbance measured at $276 \mathrm{~nm}$ against blank. Standard curve of monogalacturonic acid was used to determine the amount of reducing sugar liberated, assuming that the concentration of monogalacturonic acid is equal to the concentration of reducing sugars (Jurick et al., 2012). The unit of enzyme is expressed as $\mathrm{U} / \mathrm{mL}$, whereby the definition of $U$ is one micromole of monogalacturonic acid released per min.

\subsection{Pectin methyl esterase analysis}

\subsubsection{Pectin methyl esterase extraction}

Pectin methyl esterase (PME) extraction was conducted according to the method of Hagerman and Austin (1986). Firstly, durian was mixed thoroughly with $8.8 \%(\mathrm{w} / \mathrm{v} \mathrm{NaCl})$ solution, in the ratio of $1: 6(\mathrm{w} / \mathrm{v})$ in ice for 20 mins. Then, the mixture was centrifuged at 15 ,
$000 \times g$ for 20 mins. The supernatant was collected, filtered through filter paper (Whatman No. 1) and adjusted to $\mathrm{pH}$ 7.5. The collected extract will be used as crude enzyme for PME assay.

\subsubsection{Pectin methyl esterase (PME) assay}

Pectin methyl esterase (PME) assay was conducted according to the method of Hagerman and Austin (1986). All the solutions of pectin, bromomethyl blue indicator dye and water were adjusted to $\mathrm{pH} 7.5$ prior to analysis. Citrus pectin $(0.5 \%, \mathrm{w} / \mathrm{v})$ solution was prepared by continuous stirring at $40^{\circ} \mathrm{C}$ until fully dissolved. Bromomethyl blue $(0.01 \%)$ was dissolved in $0.003 \mathrm{M}$ potassium phosphate buffer $(\mathrm{pH}=7.5)$. A UV-Vis spectrophotometer (Cary 60, Agilent Technologies) at the wavelength of $620 \mathrm{~nm}$ was used to measure the PME activity with the temperature maintained at $25^{\circ} \mathrm{C}$. In a cuvette, solution mixture containing $2.0 \mathrm{~mL}$ pectin, 0.2 $\mathrm{mL}(\mathrm{w} / \mathrm{v})$ bromomethyl blue and $0.7 \mathrm{~mL}$ water was read by the spectrophotometer. The spectrophotometry reading remained constant for $1 \mathrm{~min}$ until $0.1 \mathrm{~mL}$ of crude enzyme is added. The reaction started when 0.1 $\mathrm{mL}$ crude enzyme was added into the cuvette and the rate of $A_{620}(A b s 620 \mathrm{~nm} / \mathrm{min}$ ) was recorded. The unit of enzyme is expressed as $\mathrm{U} / \mathrm{mL}$, whereby $U$ is defined as one micromole of galacturonic acid methyl ester released per min.

\subsection{Sensory evaluation}

Fifty panellists were involved in the sensory evaluation of the durian paste and pulp. A triangle test was used, whereby panellists were required to identify the odd sample among three given samples. The samples for evaluation were the untreated durian samples and HP -treated durian samples. For both durian paste and pulp, a significant difference between the untreated and HPtreated samples was established if a minimum of twentythree out of the fifty panellists could successfully identify the odd sample (Roessler et al., 1978).

\subsection{Statistical analysis}

All data were presented as mean \pm standard deviation $(n \geq 6)$. Analysis of variance (ANOVA) was performed using Minitab 16.1, with a 95\% confidence level (Minitab Co., Pennsylvania, USA).

\section{Results and discussion}

\subsection{Total soluble solids (TSS)}

The TSS in all untreated (control) and HP-treated durian paste and pulp (Figure 1) were not significantly different $(\mathrm{p}>0.05)$ and did not show any significant changes $(p>0.05)$ throughout the 56-day storage study period. The TSS for the untreated samples ranged from 


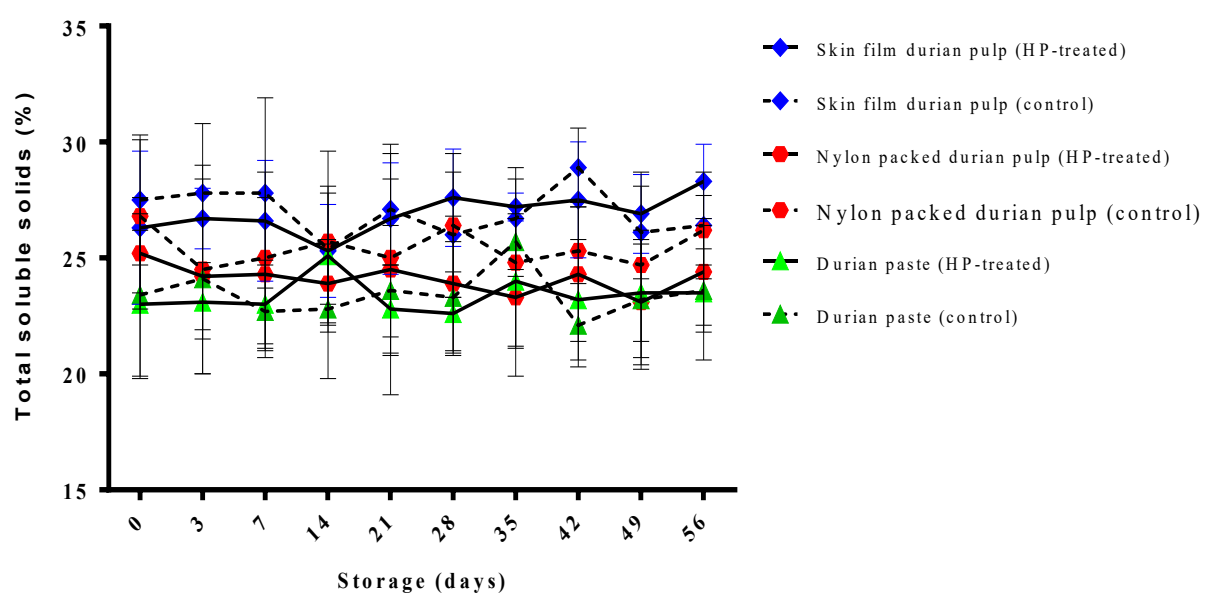

Figure 1. Changes in the total soluble solids of durian paste and pulp throughout a 56-day storage period

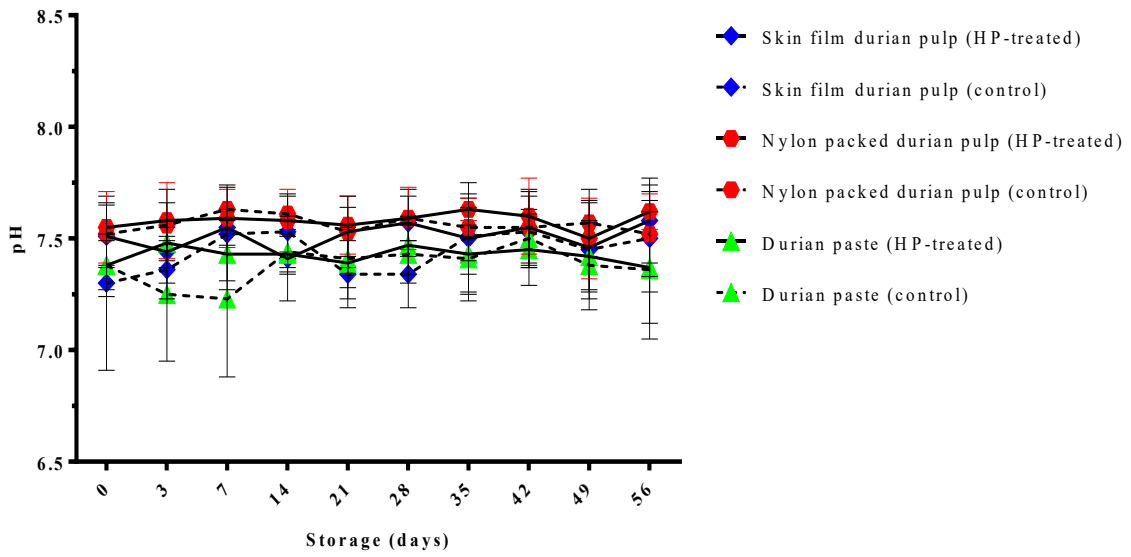

Figure 2. Changes in the $\mathrm{pH}$ of durian paste and pulp throughout a 56-day storage period

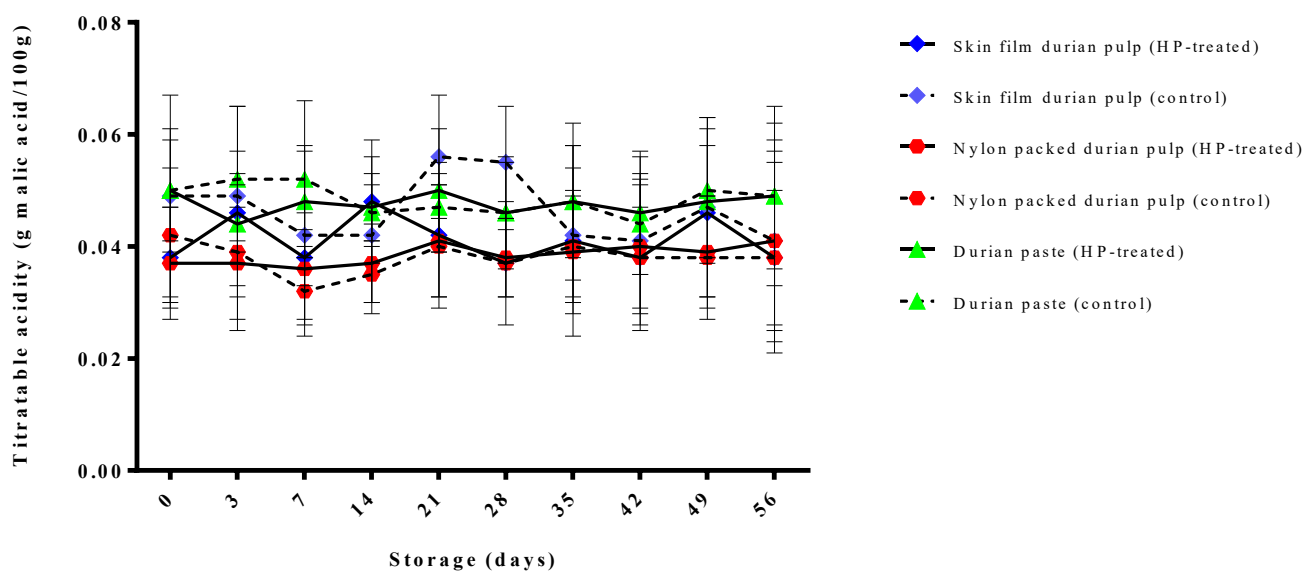

Figure 3. Changes in the titratable acidity of durian paste and pulp throughout a 56-day storage period

22.1-28.9 \%, while HP-treated samples had 22.6-28.3\% TSS. The results are comparable to the previous reported TSS values of 19.4-25\% (Ketsa and Pangkool, 1994; Pascua and Cantila, 1992; Wasnin et al., 2014). In addition, the TSS of durian pulp in different packaging materials (nylon and skin film) showed comparable TSS contents. The TSS in nylon packaged control samples were $24.5-26.8 \%$, whereas for HP-treated samples, the TSS were between 23.1-25.2\%. Meanwhile, for skin film -packaged samples, the TSS was $25.4-28.9 \%$ and 25.3 $28.3 \%$ for control and HP-treated samples, respectively.
This finding suggests that the TSS in durian were not affected by HPP and the types of packaging materials. Specifically, the change in TSS from Day 0 to 56 in both untreated and HP-treated durian samples (paste and pulp) was less than $8 \%$. This is lower than the $13 \%$ increase in TSS of durian stored for 7 weeks at 4 and $28^{\circ} \mathrm{C}$, as reported by Voon et al. (2006). These findings suggest that the dissociation or breakdown of starch to sugar in the durian samples was less severe when stored at $-18^{\circ} \mathrm{C}$, even for a 56-day storage period. High content of TSS is one of the factors that would contribute to the initiation 
of fermentation in fruits. And in our case, the initiation of the fermentation process in the durian samples is not desirable. Therefore, stable TSS value in HP-treated durian paste and pulp is desirable especially when the changes were found to be minimal for as long as 56 days.

\section{$3.2 \mathrm{pH}$ and titratable acidity}

The $\mathrm{pH}$ of durian paste and pulp are as shown in Figure 2. It could be observed that the $\mathrm{pH}$ of the durian paste and pulp (nylon- and skin film-packaged) showed no significant difference $(\mathrm{p}>0.05)$ after 56 days storage at $-18^{\circ} \mathrm{C}$, with an average $\mathrm{pH}$ of 7 observed throughout the storage period. There were no major fluctuations in the $\mathrm{pH}$ of durian paste and pulp during the 56 days of storage. From day 0 to 56 , the $\mathrm{pH}$ changes in nylon- and skin film-packaged durian paste and pulp were less than $5 \%$. A storage condition at $-18^{\circ} \mathrm{C}$ seemed to be a better storage option for the durian paste and pulp because by comparison, Voon et al. (2006) reported that the $\mathrm{pH}$ of durian remained stable for 35 days when stored at $4{ }^{\circ} \mathrm{C}$, while the $\mathrm{pH}$ was found to decrease when it was stored at $28^{\circ} \mathrm{C}$.

The $\mathrm{pH}$ is one of the measurements that could be used to determine the quality and freshness of durian. Durian with a low $\mathrm{pH}$ might be too acidic and would not be suitable for consumption, whereas a high $\mathrm{pH}$ might increase the possibility of microbial spoilage. Theoretically, the durian paste, which was well-blended during its processing, had a higher possibility of spoilage by microorganisms due to broken cell tissues and the more severe handling involved during its processing. However, in this study, the treated durian paste showed a stable $\mathrm{pH}$ throughout the storage period that was comparable to that of durian pulp. This finding potentially suggests that storage at low temperature $\left(-18^{\circ}\right.$ C), in combination with HPP, could inactivate microorganism growth and consequently slow down quality degradation of the durian paste and pulp.

The titratable acidity (Figure 3 ) of the nylon- and skin film-packaged durian paste and pulp showed no significant changes $(p>0.05)$ throughout the 56-day storage period. The result showed that the HP-treated durian samples generally had lower titratable acidity values as compared to the untreated sample. The titratable acidity in untreated samples was in the range of $0.032-0.056 \%$, whereas for HP-treated samples, the titratable acidity values were between $0.036-0.050 \%$.

\subsection{Colour}

Table 1A shows the $\mathrm{L}^{*}$ value, which is an indicator of the brightness of a sample. The $\mathrm{L}^{*}$ values of nylonpacked untreated durian pulp showed no significant differences $(p>0.05)$ throughout the 8 -week storage, while the opposite is true for the untreated durian paste and skin film-packaged durian pulp. Generally, it was found that there was a $0.14-4.0 \%$ reduction in the $L^{*}$ values of all untreated samples. In contrast, there were no significance changes $(p>0.05)$ in terms of the $L^{*}$ values of all HP-treated samples throughout the storage period. These observations suggested that HPP does not affect the brightness of the treated durian samples.

Meanwhile, the hue and chroma values of the samples are shown in Tables $1 \mathrm{~B}$ and $1 \mathrm{C}$, respectively. For both of these colour properties, the overall HPtreated samples did not show any significant changes $(p>0.05)$ throughout the storage period. However, the chroma value of the untreated durian paste and pulp varied significantly $(\mathrm{p}<0.05)$.

Overall, these results showed that the colour property of durian would not be affected by HPP treatment (Ahmed et al., 2005). In contrast, untreated samples displayed changes in their colour properties and these changes could possibly be associated with the microbial and enzyme activities in the samples. Thus, from an aesthetic point of view, HPP does not exert any impact on the total colour of processed fruits and this is supported by the findings from a previous study on the effect of HPP on apricot nectar (Huang et al., 2013). In fact, the positive effect of HPP on microbial and enzyme inactivation was beneficial in preserving the physical appearance of the durian paste and pulp.

\subsection{Microbiological activities}

Microbiological activities in the nylon-packaged durian paste and, nylon- and skin film-packaged durian pulp were reduced by HPP to non-detectable levels and remained so throughout the storage period. Specifically, HPP effectively reduced the total plate count (TPC) in the durian paste and pulp to below detection levels throughout the 8-week storage period (Table 2A). Meanwhile, for untreated samples, the microbial growth in durian paste was relatively higher as compared to that of durian pulp (for both nylon- and skin film-packaged samples). This was possibly due to the fact that the processing of durian paste involved more handling as compared to durian pulp, thus resulting in a higher risk of contamination that eventually led to higher initial microbial counts.

Furthermore, for individual presumptive microbial counts that included total presumptive coliforms (Table 2B), E. coli (Table 2C), yeast and mould (Table 2D) and psychrophilic counts (Table 2E), it was observed that all HP-treated durian samples (both paste and pulp) showed non-detectable counts. Presumptive E. coli was not detected in all samples, whereas the total presumptive 
coliforms and psychrophilic counts in untreated durian paste and skin film-packaged durian pulp were found to be slightly higher towards the end of the storage period. Yeast and mould were detected in untreated durian paste from the beginning to the end of the storage period. However, yeast and mould were only detected in nylonand skin film-packaged durian pulps starting from Day 35 (3.36 $\left.\log _{10} \mathrm{CFU} / \mathrm{g}\right)$ and Day $42\left(3.46 \log _{10} \mathrm{CFU} / \mathrm{g}\right)$, respectively. Reduction of microbiological activity by HPP such as total aerobic and yeast and mould has been reported earlier (Matser et al., 2004; Queirós et al., 2014)

\subsection{Enzymatic activity}

Polygalacturonase (PG) and pectin methyl esterase (PME) activities in durian samples are shown in Tables $3 \mathrm{~A}$ and $3 \mathrm{~B}$, respectively. All the HP-treated durian samples showed lower enzyme activities (PG and PME) than the control sample. In addition, it was found that all PG and PME activities showed a decreasing trend

Table 1A. Changes in the L* values of durian samples throughout the 56-day storage period.

\begin{tabular}{|c|c|c|c|c|c|c|}
\hline \multirow[t]{2}{*}{ Day of storage } & \multicolumn{2}{|c|}{ Durian paste } & \multicolumn{2}{|c|}{$\begin{array}{c}\text { Durian pulp } \\
\text { (nylon packaging) }\end{array}$} & \multicolumn{2}{|c|}{$\begin{array}{c}\text { Durian pulp } \\
\text { (skin film packaging) }\end{array}$} \\
\hline & Control & HP-treated & Control & HP-treated & Control & HP-treated \\
\hline 0 & $78.12 \pm 1.27^{\mathrm{ab}}$ & $78.01 \pm 3.30^{\mathrm{a}}$ & $76.95 \pm 0.79^{\mathrm{a}}$ & $76.75 \pm 1.32^{\mathrm{a}}$ & $81.22 \pm 0.69^{\mathrm{a}}$ & $77.72 \pm 0.27^{b}$ \\
\hline 3 & $77.12 \pm 1.55^{a b c}$ & $76.64 \pm 1.72^{\mathrm{a}}$ & $77.43 \pm 1.93^{\mathrm{a}}$ & $77.29 \pm 0.51^{\mathrm{a}}$ & $79.49 \pm 0.54^{\mathrm{ab}}$ & $78.36 \pm 0.57^{\mathrm{ab}}$ \\
\hline 7 & $78.13 \pm 0.52^{a b}$ & $76.91 \pm 1.24^{\mathrm{a}}$ & $78.32 \pm 1.03^{\mathrm{a}}$ & $78.06 \pm 3.16^{\mathrm{a}}$ & $79.16 \pm 1.98^{a b}$ & $77.89 \pm 0.83^{a b}$ \\
\hline 14 & $78.20 \pm 0.34^{\mathrm{a}}$ & $78.23 \pm 0.28^{\mathrm{a}}$ & $77.16 \pm 0.89^{\mathrm{a}}$ & $78.39 \pm 0.28^{\mathrm{a}}$ & $76.83 \pm 1.54^{b}$ & $78.49 \pm 1.12^{a b}$ \\
\hline 21 & $77.16 \pm 0.44^{a b c}$ & $76.38 \pm 0.54^{\mathrm{a}}$ & $77.79 \pm 1.02^{\mathrm{a}}$ & $77.75 \pm 2.48^{\mathrm{a}}$ & $78.52 \pm 2.14^{\mathrm{ab}}$ & $78.20 \pm 1.41^{\mathrm{ab}}$ \\
\hline 28 & $78.18 \pm 0.83^{a b}$ & $77.21 \pm 0.67^{\mathrm{a}}$ & $78.19 \pm 1.45^{\mathrm{a}}$ & $76.79 \pm 1.34^{\mathrm{a}}$ & $77.09 \pm 2.73^{b}$ & $79.69 \pm 0.74^{\mathrm{a}}$ \\
\hline 35 & $76.61 \pm 1.77^{\mathrm{abc}}$ & $77.00 \pm 0.95^{\mathrm{a}}$ & $77.32 \pm 1.37^{\mathrm{a}}$ & $76.29 \pm 0.31^{\mathrm{a}}$ & $76.96 \pm 1.06^{\mathrm{b}}$ & $76.79 \pm 0.77^{b}$ \\
\hline 42 & $77.72 \pm 0.45^{\mathrm{ab}}$ & $76.22 \pm 0.87^{\mathrm{a}}$ & $78.08 \pm 0.93^{\mathrm{a}}$ & $76.51 \pm 0.38^{\mathrm{a}}$ & $76.80 \pm 2.13^{b}$ & $76.86 \pm 1.31^{b}$ \\
\hline 49 & $75.50 \pm 1.47^{\mathrm{c}}$ & $75.56 \pm 1.02^{\mathrm{a}}$ & $76.65 \pm 1.00^{\mathrm{a}}$ & $76.23 \pm 2.21^{\mathrm{a}}$ & $77.69 \pm 0.83^{b}$ & $77.46 \pm 1.14^{b}$ \\
\hline 56 & $76.02 \pm 1.48^{b c}$ & $76.29 \pm 1.25^{\mathrm{a}}$ & $76.84 \pm 1.23^{\mathrm{a}}$ & $75.87 \pm 2.22^{\mathrm{a}}$ & $78.01 \pm 1.24^{\mathrm{b}}$ & $77.69 \pm 1.20^{b}$ \\
\hline
\end{tabular}

All values are expressed as mean $\pm \mathrm{SD}(\mathrm{n}=6)$. Means with different alphabet superscript $(\mathrm{p}<0.05)$ indicate significant difference within the same column.

Table 1B. Changes in the hue values of durian samples throughout the 56-day storage period.

\begin{tabular}{|c|c|c|c|c|c|c|}
\hline \multirow[t]{2}{*}{ Day of storage } & \multicolumn{2}{|c|}{ Durian paste } & \multicolumn{2}{|c|}{$\begin{array}{c}\text { Durian pulp } \\
\text { (nylon packaging) }\end{array}$} & \multicolumn{2}{|c|}{$\begin{array}{c}\text { Durian pulp } \\
\text { (skin film packaging) }\end{array}$} \\
\hline & Control & HP-treated & Control & HP-treated & Control & HP-treated \\
\hline 0 & $86.98 \pm 1.14^{\mathrm{ab}}$ & $86.23 \pm 0.55^{\mathrm{a}}$ & $87.59 \pm 0.53^{a}$ & $87.30 \pm 0.51^{\mathrm{a}}$ & $86.75 \pm 0.05^{\mathrm{ab}}$ & $88.24 \pm 0.60^{\mathrm{ab}}$ \\
\hline 3 & $86.69 \pm 1.27^{\mathrm{ab}}$ & $87.42 \pm 1.21^{\mathrm{a}}$ & $87.28 \pm 1.40^{\mathrm{a}}$ & $86.38 \pm 0.36^{\mathrm{a}}$ & $86.84 \pm 0.10^{\mathrm{ab}}$ & $87.08 \pm 0.69^{c}$ \\
\hline 7 & $86.11 \pm 1.22^{b}$ & $86.12 \pm 0.86^{\mathrm{a}}$ & $87.80 \pm 0.68^{a}$ & $86.31 \pm 0.84^{\mathrm{a}}$ & $87.39 \pm 0.66^{\mathrm{ab}}$ & $88.43 \pm 1.11^{\mathrm{a}}$ \\
\hline 14 & $86.72 \pm 0.22^{\mathrm{ab}}$ & $86.34 \pm 0.55^{\mathrm{a}}$ & $86.88 \pm 0.51^{\mathrm{ab}}$ & $86.68 \pm 1.23^{\mathrm{a}}$ & $86.20 \pm 0.66^{\mathrm{ab}}$ & $87.55 \pm 0.28^{a b c}$ \\
\hline 21 & $86.92 \pm 0.48^{\mathrm{ab}}$ & $86.66 \pm 0.22^{\mathrm{a}}$ & $86.52 \pm 1.49^{\mathrm{ab}}$ & $87.21 \pm 0.41^{\mathrm{a}}$ & $87.86 \pm 0.43^{\mathrm{a}}$ & $87.20 \pm 0.34^{b c}$ \\
\hline 28 & $88.00 \pm 0.97^{\mathrm{a}}$ & $87.21 \pm 0.81^{\mathrm{a}}$ & $86.37 \pm 0.89^{a b}$ & $87.56 \pm 0.33^{a}$ & $87.68 \pm 0.41^{\mathrm{a}}$ & $88.53 \pm 0.24^{\mathrm{a}}$ \\
\hline 35 & $85.72 \pm 0.12^{b}$ & $86.83 \pm 0.29^{\mathrm{a}}$ & $86.25 \pm 0.91^{a b}$ & $87.32 \pm 0.17^{\mathrm{a}}$ & $85.95 \pm 1.92^{b}$ & $87.02 \pm 0.63^{c}$ \\
\hline 42 & $87.03 \pm 0.48^{a b}$ & $87.12 \pm 0.49^{a}$ & $86.81 \pm 0.20^{\mathrm{ab}}$ & $87.55 \pm 0.54^{\mathrm{a}}$ & $87.07 \pm 0.15^{\mathrm{ab}}$ & $87.73 \pm 0.40^{\mathrm{abc}}$ \\
\hline 49 & $85.67 \pm 0.84^{b}$ & $87.16 \pm 0.68^{a}$ & $85.31 \pm 1.51^{b}$ & $86.79 \pm 0.87^{\mathrm{a}}$ & $86.94 \pm 1.50^{\mathrm{ab}}$ & $87.97 \pm 0.38^{a b c}$ \\
\hline 56 & $85.55 \pm 0.61^{b}$ & $86.80 \pm 1.09^{\mathrm{a}}$ & $85.93 \pm 0.70^{a b}$ & $87.08 \pm 1.10^{\mathrm{a}}$ & $86.37 \pm 0.94^{\mathrm{ab}}$ & $87.97 \pm 0.38^{\mathrm{abc}}$ \\
\hline
\end{tabular}

All values are expressed as mean \pm SD $(n=6)$. Means with different alphabet superscript $(\mathrm{p}<0.05)$ indicate significant difference within the same column.

Table 1C. Changes in the chroma values of durian samples throughout the 56-day storage period.

\begin{tabular}{|c|c|c|c|c|c|c|}
\hline \multirow[t]{2}{*}{ Day of storage } & \multicolumn{2}{|c|}{ Durian paste } & \multicolumn{2}{|c|}{$\begin{array}{c}\text { Durian pulp } \\
\text { (nylon packaging) }\end{array}$} & \multicolumn{2}{|c|}{$\begin{array}{c}\text { Durian pulp } \\
\text { (skin film packaging) }\end{array}$} \\
\hline & Control & HP-treated & Control & HP-treated & Control & HP-treated \\
\hline 0 & $20.64 \pm 0.74^{b}$ & $22.38 \pm 1.10^{\mathrm{a}}$ & $30.32 \pm 0.42^{a b}$ & $30.67 \pm 2.04^{\mathrm{a}}$ & $34.24 \pm 0.59^{\mathrm{a}}$ & $32.35 \pm 3.54^{\mathrm{a}}$ \\
\hline 3 & $22.53 \pm 0.57^{\mathrm{ab}}$ & $23.98 \pm 4.71^{\mathrm{a}}$ & $30.89 \pm 3.53^{\mathrm{ab}}$ & $32.13 \pm 1.65^{\mathrm{a}}$ & $30.23 \pm 2.22^{\mathrm{cd}}$ & $35.39 \pm 2.30^{\mathrm{a}}$ \\
\hline 7 & $22.12 \pm 0.17^{\mathrm{ab}}$ & $23.29 \pm 1.38^{\mathrm{a}}$ & $30.67 \pm 0.23^{a b}$ & $32.21 \pm 1.73^{\mathrm{a}}$ & $33.91 \pm 1.05^{\mathrm{ab}}$ & $33.32 \pm 1.39^{\mathrm{a}}$ \\
\hline 14 & $21.30 \pm 0.79^{b}$ & $23.29 \pm 0.75^{\mathrm{a}}$ & $29.36 \pm 1.92^{a b}$ & $28.51 \pm 1.64^{\mathrm{a}}$ & $32.91 \pm 1.81^{\mathrm{abc}}$ & $33.96 \pm 0.83^{\mathrm{a}}$ \\
\hline 21 & $22.04 \pm 0.63^{\mathrm{ab}}$ & $23.73 \pm 1.75^{\mathrm{a}}$ & $30.28 \pm 2.92^{\mathrm{ab}}$ & $28.90 \pm 1.88^{\mathrm{a}}$ & $29.47 \pm 1.65^{\mathrm{cd}}$ & $31.39 \pm 3.07^{\mathrm{a}}$ \\
\hline 28 & $20.48 \pm 0.63^{b}$ & $22.68 \pm 0.18^{\mathrm{a}}$ & $32.56 \pm 1.24^{\mathrm{ab}}$ & $30.63 \pm 1.55^{\mathrm{a}}$ & $30.52 \pm 0.83^{b c d}$ & $32.62 \pm 1.91^{\mathrm{a}}$ \\
\hline 35 & $22.42 \pm 1.23^{\mathrm{ab}}$ & $21.84 \pm 0.94^{\mathrm{a}}$ & $31.92 \pm 1.48^{a b}$ & $29.75 \pm 2.03^{\mathrm{a}}$ & $28.64 \pm 2.73^{\mathrm{d}}$ & $32.32 \pm 2.39^{\mathrm{a}}$ \\
\hline 42 & $23.58 \pm 2.22^{\mathrm{a}}$ & $23.44 \pm 1.62^{\mathrm{a}}$ & $32.74 \pm 1.31^{\mathrm{a}}$ & $32.02 \pm 0.40^{\mathrm{a}}$ & $27.16 \pm 0.82^{\mathrm{d}}$ & $31.41 \pm 3.17^{\mathrm{a}}$ \\
\hline 49 & $21.00 \pm 1.58^{b}$ & $24.88 \pm 1.44^{\mathrm{a}}$ & $29.07 \pm 1.25^{b}$ & $29.21 \pm 4.02^{\mathrm{a}}$ & $28.65 \pm 2.54^{\mathrm{d}}$ & $31.87 \pm 1.30^{\mathrm{a}}$ \\
\hline 56 & $21.17 \pm 1.44^{\mathrm{b}}$ & $25.14 \pm 1.89^{\mathrm{a}}$ & $31.16 \pm 2.25^{\mathrm{ab}}$ & $29.11 \pm 3.72^{\mathrm{a}}$ & $28.85 \pm 2.65^{\mathrm{d}}$ & $32.21 \pm 0.94^{\mathrm{a}}$ \\
\hline
\end{tabular}

All values are expressed as mean \pm SD $(n=6)$. Means with different alphabet superscript $(\mathrm{p}<0.05)$ indicate significant difference within the same column. 
Table 2A. Total plate count of durian samples throughout the 56-day storage period.

\begin{tabular}{|c|c|c|c|c|c|c|}
\hline \multicolumn{7}{|c|}{ Total plate count $\left(\log _{10} \mathrm{CFU} / \mathrm{g}\right)$} \\
\hline \multirow{2}{*}{$\begin{array}{l}\text { Day of } \\
\text { storage }\end{array}$} & \multicolumn{2}{|c|}{ Durian paste } & \multicolumn{2}{|c|}{$\begin{array}{c}\text { Durian pulp } \\
\text { (nylon packaging) }\end{array}$} & \multicolumn{2}{|c|}{$\begin{array}{c}\text { Durian pulp } \\
\text { (skin film packaging) }\end{array}$} \\
\hline & Control & HP-treated & Control & HP-treated & Control & HP-treated \\
\hline 0 & 3.76 & ND & 3.93 & ND & 3.69 & ND \\
\hline 3 & 3.93 & ND & 3.91 & ND & 3.70 & ND \\
\hline 7 & 4.41 & ND & 3.89 & ND & 3.67 & ND \\
\hline 14 & 4.41 & ND & 3.95 & ND & 3.70 & ND \\
\hline 21 & 4.48 & ND & 3.97 & ND & 3.76 & ND \\
\hline 28 & 4.67 & ND & 3.96 & ND & 3.81 & ND \\
\hline 35 & 4.88 & ND & 3.96 & ND & 3.76 & ND \\
\hline 42 & 4.90 & ND & 3.96 & ND & 3.86 & ND \\
\hline 49 & 4.92 & ND & 3.96 & ND & 3.97 & ND \\
\hline 56 & 4.97 & ND & 3.99 & ND & 4.08 & ND \\
\hline
\end{tabular}

ND: not detected, $<20 \mathrm{CFU} / \mathrm{g}$ estimated

Table 2B. Total presumptive coliform in durian samples throughout the 56-day storage period.

\begin{tabular}{|c|c|c|c|c|c|c|}
\hline \multicolumn{7}{|c|}{ Total presumptive coliform $\left(\log _{10} \mathrm{CFU} / \mathrm{g}\right)$} \\
\hline \multirow{2}{*}{$\begin{array}{l}\text { Day of } \\
\text { storage }\end{array}$} & \multicolumn{2}{|c|}{ Durian paste } & \multicolumn{2}{|c|}{$\begin{array}{c}\text { Durian pulp } \\
\text { (nylon packaging) }\end{array}$} & \multicolumn{2}{|c|}{$\begin{array}{c}\text { Durian pulp } \\
\text { (skin film packaging) }\end{array}$} \\
\hline & Control & HP-treated & Control & HP-treated & Control & HP-treated \\
\hline 0 & ND & ND & ND & ND & ND & ND \\
\hline 3 & ND & ND & ND & ND & ND & ND \\
\hline 7 & ND & ND & ND & ND & ND & ND \\
\hline 14 & ND & ND & ND & ND & ND & ND \\
\hline 21 & ND & ND & ND & ND & ND & ND \\
\hline 28 & ND & ND & ND & ND & ND & ND \\
\hline 35 & ND & ND & ND & ND & 3.34 & ND \\
\hline 42 & ND & ND & ND & ND & 3.36 & ND \\
\hline 49 & 3.43 & ND & ND & ND & 3.36 & ND \\
\hline 56 & 3.34 & ND & ND & ND & 3.38 & ND \\
\hline
\end{tabular}

ND: not detected, $<20 \mathrm{CFU} / \mathrm{g}$ estimated

Table 2C. Total presumptive $E$. coli in durian samples throughout the 56-day storage period.

\begin{tabular}{|c|c|c|c|c|c|c|}
\hline \multicolumn{7}{|c|}{ Total presumptive $E$. coli $\left(\log _{10} \mathrm{CFU} / \mathrm{g}\right)$} \\
\hline \multirow{2}{*}{$\begin{array}{l}\text { Day of } \\
\text { storage }\end{array}$} & \multicolumn{2}{|c|}{ Durian paste } & \multicolumn{2}{|c|}{$\begin{array}{c}\text { Durian pulp } \\
\text { (nylon packaging) }\end{array}$} & \multicolumn{2}{|c|}{$\begin{array}{c}\text { Durian pulp } \\
\text { (skin film packaging) }\end{array}$} \\
\hline & Control & HP-treated & Control & HP-treated & Control & HP-treated \\
\hline 0 & ND & ND & ND & ND & ND & ND \\
\hline 3 & ND & ND & ND & ND & ND & ND \\
\hline 7 & ND & ND & ND & ND & ND & ND \\
\hline 14 & ND & ND & ND & ND & ND & ND \\
\hline 21 & ND & ND & ND & ND & ND & ND \\
\hline 28 & ND & ND & ND & ND & ND & ND \\
\hline 35 & ND & ND & ND & ND & ND & ND \\
\hline 42 & ND & ND & ND & ND & ND & ND \\
\hline 49 & ND & ND & ND & ND & ND & ND \\
\hline 56 & ND & ND & ND & ND & ND & ND \\
\hline
\end{tabular}

ND: not detected, $<20 \mathrm{CFU} / \mathrm{g}$ estimated

Table 2D. Yeast and mould count in durian samples throughout the 56-day storage period.

\begin{tabular}{|c|c|c|c|c|c|c|}
\hline \multicolumn{7}{|c|}{ Yeast and mould count $\left(\log _{10} \mathrm{CFU} / \mathrm{g}\right)$} \\
\hline \multirow{2}{*}{$\begin{array}{l}\text { Day of } \\
\text { storage }\end{array}$} & \multicolumn{2}{|c|}{ Durian paste } & \multicolumn{2}{|c|}{$\begin{array}{c}\text { Durian pulp } \\
\text { (nylon packaging) }\end{array}$} & \multicolumn{2}{|c|}{$\begin{array}{c}\text { Durian pulp } \\
\text { (skin film packaging) }\end{array}$} \\
\hline & Control & HP-treated & Control & HP-treated & Control & HP-treated \\
\hline 0 & 3.38 & ND & ND & ND & ND & ND \\
\hline 3 & 3.40 & ND & ND & ND & ND & ND \\
\hline 7 & 3.32 & ND & ND & ND & ND & ND \\
\hline 14 & 3.36 & ND & ND & ND & ND & ND \\
\hline 21 & 3.40 & ND & ND & ND & ND & ND \\
\hline 28 & 3.56 & ND & ND & ND & ND & ND \\
\hline 35 & 3.58 & ND & 3.36 & ND & ND & ND \\
\hline 42 & 3.77 & ND & 3.34 & ND & 3.46 & ND \\
\hline 49 & 3.76 & ND & 3.36 & ND & 3.49 & ND \\
\hline 56 & 3.78 & ND & 3.41 & ND & 3.79 & ND \\
\hline
\end{tabular}

ND: not detected, $<20 \mathrm{CFU} / \mathrm{g}$ estimated 
Table 2E. Psychrophilic microorganisms count in durian samples throughout the 56-day storage period.

\begin{tabular}{|c|c|c|c|c|c|c|}
\hline \multicolumn{7}{|c|}{ Psychrophilic count $\left(\log _{10} \mathrm{CFU} / \mathrm{g}\right)$} \\
\hline \multirow{2}{*}{$\begin{array}{l}\text { Day of } \\
\text { storage }\end{array}$} & \multicolumn{2}{|c|}{ Durian paste } & \multicolumn{2}{|c|}{$\begin{array}{c}\text { Durian pulp } \\
\text { (nylon packaging) }\end{array}$} & \multicolumn{2}{|c|}{$\begin{array}{c}\text { Durian pulp } \\
\text { (skin film packaging) }\end{array}$} \\
\hline & Control & HP-treated & Control & HP-treated & Control & HP-treated \\
\hline 0 & ND & ND & ND & ND & ND & ND \\
\hline 3 & ND & ND & ND & ND & ND & ND \\
\hline 7 & ND & ND & ND & ND & ND & ND \\
\hline 14 & ND & ND & ND & ND & ND & ND \\
\hline 21 & ND & ND & ND & ND & ND & ND \\
\hline 28 & ND & ND & ND & ND & ND & ND \\
\hline 35 & ND & ND & ND & ND & ND & ND \\
\hline 42 & 3.32 & ND & ND & ND & ND & ND \\
\hline 49 & 3.32 & ND & ND & ND & 3.36 & ND \\
\hline 56 & 3.40 & ND & ND & ND & 3.32 & ND \\
\hline
\end{tabular}

ND: not detected, $<20 \mathrm{CFU} / \mathrm{g}$ estimated

Table 3A. Polygalacturonase activity in durian samples throughout the 56-day storage period.

\begin{tabular}{|c|c|c|c|c|c|c|}
\hline \multicolumn{7}{|c|}{ Polygalacturonase activity $(\mathrm{U} / \mathrm{mL})$} \\
\hline \multirow{2}{*}{$\begin{array}{l}\text { Day of } \\
\text { storage }\end{array}$} & \multicolumn{2}{|c|}{ Durian paste } & \multicolumn{2}{|c|}{$\begin{array}{c}\text { Durian pulp } \\
\text { (nylon packaging) }\end{array}$} & \multicolumn{2}{|c|}{$\begin{array}{c}\text { Durian pulp } \\
\text { (skin film packaging) }\end{array}$} \\
\hline & Control & HP-treated & Control & HP-treated & Control & HP-treated \\
\hline 0 & $308.9 \pm 23.3^{\mathrm{bcd}}$ & $238.2 \pm 31.9^{\mathrm{cd}}$ & $671.0 \pm 106.4^{\mathrm{a}}$ & $490.3 \pm 38.6^{b}$ & $438.8 \pm 4.0^{\mathrm{ab}}$ & $364.5 \pm 25.9^{a b}$ \\
\hline 3 & $386.63 \pm 26.7^{\mathrm{ab}}$ & $337.8 \pm 51.5^{\mathrm{a}}$ & $501.9 \pm 51.6^{\mathrm{b}}$ & $377.1 \pm 55.7^{\mathrm{d}}$ & $458.9 \pm 63.6^{\mathrm{ab}}$ & $298.0 \pm 16.3^{\text {bcde }}$ \\
\hline 7 & $425.2 \pm 82.6^{\mathrm{a}}$ & $297.4 \pm 36.8^{a b}$ & $686.4 \pm 38.4^{\mathrm{a}}$ & $483.8 \pm 55.1^{\mathrm{bc}}$ & $482.6 \pm 17.3^{\mathrm{a}}$ & $378.4 \pm 99.9^{\mathrm{a}}$ \\
\hline 14 & $361.9 \pm 75.0^{\mathrm{abc}}$ & $252.34 \pm 5.5^{b c}$ & $511.2 \pm 10.1^{b}$ & $383.6 \pm 32.6^{\mathrm{d}}$ & $381.1 \pm 75.7^{\mathrm{bc}}$ & $295.3 \pm 4.4^{\text {bcde }}$ \\
\hline 21 & $330.1 \pm 30.5^{\mathrm{bcd}}$ & $254.6 \pm 12.3^{\mathrm{bc}}$ & $680.8 \pm 29.2^{\mathrm{a}}$ & $562.3 \pm 6.9^{\mathrm{a}}$ & $474.6 \pm 64.3^{\mathrm{a}}$ & $360.8 \pm 45.8^{\mathrm{ab}}$ \\
\hline 28 & $338.8 \pm 56.4^{\mathrm{bcd}}$ & $201.9 \pm 3.2^{\mathrm{de}}$ & $383.4 \pm 31.9^{\mathrm{c}}$ & $306.7 \pm 6.7^{\mathrm{e}}$ & $298.1 \pm 16.2^{\mathrm{d}}$ & $270.7 \pm 8.3^{\text {cde }}$ \\
\hline 35 & $273.3 \pm 12.9^{\mathrm{de}}$ & $193.4 \pm 4.8^{\mathrm{de}}$ & $356.3 \pm 21.8^{c}$ & $294.7 \pm 32.3^{\mathrm{e}}$ & $388.5 \pm 33.0^{b c}$ & $302.3 \pm 26.1^{\mathrm{bcd}}$ \\
\hline 42 & $222.0 \pm 3.5^{\mathrm{e}}$ & $165.1 \pm 14.7^{\mathrm{d}}$ & $324.3 \pm 4.9^{c}$ & $244.7 \pm 25.6^{\mathrm{e}}$ & $299.4 \pm 0.8^{\mathrm{d}}$ & $227.8 \pm 27.7^{\mathrm{e}}$ \\
\hline 49 & $273.0 \pm 13.1^{\mathrm{de}}$ & $202.2 \pm 19.2^{\mathrm{de}}$ & $701.4 \pm 4.6^{\mathrm{a}}$ & $427.4 \pm 5.8^{\mathrm{cd}}$ & $436.1 \pm 24.6^{\mathrm{ab}}$ & $340.6 \pm 5.5^{a b c}$ \\
\hline 56 & $289.6 \pm 11.7^{\mathrm{cde}}$ & $227.1 \pm 16.9^{\mathrm{cd}}$ & $504.1 \pm 29.7^{b}$ & $380.4 \pm 1.3^{\mathrm{d}}$ & $336.3 \pm 21.6^{\mathrm{cd}}$ & $233.9 \pm 7.7^{\mathrm{de}}$ \\
\hline
\end{tabular}

All values are expressed as mean $\pm \operatorname{SD}(n \geq 6)$. Means with different alphabet superscript $(\mathrm{p}<0.05)$ indicate significant difference within the same column.

Table 3B. Pectin methyl esterase activity in durian samples throughout the 56-day storage period.

\begin{tabular}{|c|c|c|c|c|c|c|}
\hline \multicolumn{7}{|c|}{ Pectin methyl esterase activity (U/mL) } \\
\hline \multirow{2}{*}{$\begin{array}{l}\text { Day of } \\
\text { storage }\end{array}$} & \multicolumn{2}{|c|}{ Durian paste } & \multicolumn{2}{|c|}{$\begin{array}{c}\text { Durian pulp } \\
\text { (nylon packaging) }\end{array}$} & \multicolumn{2}{|c|}{$\begin{array}{c}\text { Durian pulp } \\
\text { (skin film packaging) }\end{array}$} \\
\hline & Control & HP-treated & Control & HP-treated & Control & HP-treated \\
\hline 0 & $3.34 \pm 0.39^{\mathrm{a}}$ & $3.13 \pm 0.46^{\mathrm{a}}$ & $4.59 \pm 1.41^{\mathrm{a}}$ & $4.48 \pm 0.84^{\mathrm{a}}$ & $5.91 \pm 1.54^{\mathrm{ab}}$ & $5.86 \pm 0.81^{\mathrm{a}}$ \\
\hline 3 & $3.66 \pm 0.58^{a}$ & $3.41 \pm 0.44^{\mathrm{a}}$ & $4.64 \pm 0.90^{\mathrm{a}}$ & $4.62 \pm 1.56^{\mathrm{a}}$ & $5.84 \pm 1.40^{\mathrm{ab}}$ & $5.77 \pm 1.33^{\mathrm{a}}$ \\
\hline 7 & $3.81 \pm 0.72^{\mathrm{a}}$ & $3.61 \pm 0.89^{\mathrm{a}}$ & $4.44 \pm 1.27^{\mathrm{a}}$ & $4.41 \pm 1.51^{\mathrm{a}}$ & $4.70 \pm 1.06^{\mathrm{ab}}$ & $4.65 \pm 1.55^{\mathrm{a}}$ \\
\hline 14 & $4.90 \pm 0.61^{\mathrm{a}}$ & $3.88 \pm 0.60^{\mathrm{a}}$ & $6.31 \pm 0.46^{\mathrm{a}}$ & $6.30 \pm 1.32^{\mathrm{a}}$ & $6.91 \pm 1.35^{\mathrm{a}}$ & $4.04 \pm 1.57^{\mathrm{a}}$ \\
\hline 21 & $4.39 \pm 0.85^{\mathrm{a}}$ & $4.13 \pm 0.72^{\mathrm{a}}$ & $6.01 \pm 1.10^{\mathrm{a}}$ & $6.01 \pm 0.78^{\mathrm{a}}$ & $6.28 \pm 1.02^{a b}$ & $5.30 \pm 1.31^{\mathrm{a}}$ \\
\hline 28 & $5.01 \pm 1.63^{\mathrm{a}}$ & $4.06 \pm 0.22^{\mathrm{a}}$ & $5.80 \pm 1.17^{\mathrm{a}}$ & $5.79 \pm 0.79^{\mathrm{a}}$ & $5.49 \pm 1.05^{\mathrm{ab}}$ & $5.31 \pm 1.34^{\mathrm{a}}$ \\
\hline 35 & $3.96 \pm 1.13^{\mathrm{a}}$ & $3.01 \pm 0.81^{\mathrm{a}}$ & $5.45 \pm 1.91^{\mathrm{a}}$ & $4.52 \pm 1.58^{\mathrm{a}}$ & $4.52 \pm 1.58^{b}$ & $4.27 \pm 1.36^{\mathrm{a}}$ \\
\hline 42 & $4.98 \pm 0.72^{a}$ & $3.48 \pm 0.50^{\mathrm{a}}$ & $5.01 \pm 1.63^{\mathrm{a}}$ & $4.04 \pm 1.59^{\mathrm{a}}$ & $6.94 \pm 0.87^{\mathrm{a}}$ & $5.08 \pm 0.92^{\mathrm{a}}$ \\
\hline 49 & $3.53 \pm 0.89^{a}$ & $3.15 \pm 0.39^{\mathrm{a}}$ & $4.60 \pm 1.72^{a}$ & $4.21 \pm 0.91^{\mathrm{a}}$ & $5.99 \pm 0.52^{a b}$ & $4.55 \pm 0.76^{a}$ \\
\hline 56 & $3.64 \pm 0.74^{\mathrm{a}}$ & $3.25 \pm 0.57^{\mathrm{a}}$ & $5.17 \pm 0.93^{\mathrm{a}}$ & $5.01 \pm 0.54^{\mathrm{a}}$ & $4.42 \pm 1.37^{b}$ & $4.40 \pm 0.46^{\mathrm{a}}$ \\
\hline
\end{tabular}

All values are expressed as mean $\pm \operatorname{SD}(n \geq 6)$. Means with different alphabet superscript $(\mathrm{p}<0.05)$ indicate significant difference within the same column.

throughout the storage period. By comparing the untreated with HP-treated durian samples at the end of the storage period (Day 56), the PG activity was reduced to approximately $21.58 \%$ in durian paste, $24.54 \%$ in nylon-packaged durian pulp and $30.45 \%$ in skin filmpackaged durian pulp. In general, the PG activity in all HP-treated durian samples was at least 9.2\% lower than that in the untreated durian samples.

The PME activity in all HP-treated durian samples were also shown to be lower than that in untreated samples (Table 3B). There were no major changes in the PME from Day 0 until Day 56. By similarly comparing the untreated with HP-treated durian samples at storage Day 56, the PME activity was reduced to approximately $5.52 \%$ in durian paste, $0.45 \%$ in skin film-packaged durian pulp and $3.09 \%$ in nylon-packaged pulp. Generally, the PME activity of HP-treated was at least $0.16 \%$ lower than that of untreated samples. This finding is in line with that of another study (Hendrickx et al., 1998), in which the reduction of enzymatic activity in HP-treated food products was reported. 
Overall, in this study, it was shown that the enzymatic activities in HP-treated durian was relatively lower than those in untreated samples, irrespective of the type of packaging materials used.

\subsection{Sensory evaluation}

Based on the triangle test, correct responses of $18 / 50,21 / 50$ and 20/50 for nylon-packaged durian paste, nylon-packaged durian pulp and skin film-packaged durian pulp, respectively, were obtained. Therefore, it could be concluded that there were no significant differences between untreated and HP-treated durian samples, irrespective of the packaging material used. The texture and overall appearance of HP-treated durian were deduced to be similar to those of the control samples. Similar findings were also reported in a previous study on milk and soy-smoothies (Andrés et al., 2016), whereby no significant difference was observed in terms of the sensorial quality between HP-treated product and untreated product.

\section{Conclusion}

HPP is an alternative method that is ideal for the processing of durian samples. HPP exerted no significance effect $(\mathrm{p}>0.05)$ on the physical properties (total soluble solid, $\mathrm{pH}$, titratable acidity and colour) of durian. HPP also played important roles in the inactivation of microorganism and reduction of enzymatic activities in both nylon- and skin filmpackaged durian samples. More importantly, in terms of consumer's perception, the HP-treated durian samples showed comparable sensorial qualities to those of untreated samples. In summary, HPP provided a possibility in extending the shelf life and maintaining the quality of durian paste and pulp. HPP may also provide a solution to the issues of seasonal supply and high demands for durian.

\section{Acknowledgement}

The work was supported by the Putra Grant, Universiti Putra Malaysia (project number GPIPS/2016/9496900).

\section{References}

Ahmed, J., Ramaswamy, H.S. and Hiremath, N. (2005). The effect of high-pressure treatment on rheological characteristics and colour of mango pulp. International Journal of Food Science and Technology 40(8), 885-895. https://doi.org/10.1111/ j.1365-2621.2005.01026.x

Amid, M., Manap, Y., Azmira, F., Hussin, M. and Sarker, Z.I. (2015). A novel liquid/liquid extraction process composed of surfactant and acetonitrile for purification of polygalacturonase enzyme from Durio zibethinus. Journal of Chromatography B, 993, 1-8. https://doi.org/10.1016/ j.jchromb.2015.04.034

Ammala, A. (2011). 9 - Nylon-MXD6 resins for food packaging A2 - Lagarón, José-María, Multifunctional and Nanoreinforced Polymers for Food Packaging. Woodhead Publishing, pp. 243260.

Andrés, V., Villanueva, M.-J. and Tenorio, M.-D. (2016). Influence of high-pressure processing on microbial shelf life, sensory profile, soluble sugars, organic acids, and mineral content of milk-and soysmoothies. LWT-food Science and Technology, 65, 98-105. https://doi.org/10.1016/j.lwt.2015.07.066

Arancibia-Avila, P., Toledo, F., Park, Y.-S., Jung, S.-T., Kang, S.-G., Heo, B.G., Lee, S.-H., Sajewicz, M., Kowalska, T. and Gorinstein, S. (2008). Antioxidant properties of durian fruit as influenced by ripening. LWT-food Science and Technology, 41(10), 21182125. https://doi.org/10.1016/j.lwt.2007.12.001

Bekele, S. (1990). Peelable barrier film for vacuum skin packages and the like. Patent No.:4886690. United States

Boynton, B.B., Sims, C., Sargent, S., Balaban, M. and Marshall, M. (2002). Quality and Stability of Precut Mangos and Carambolas Subjected to High-Pressure Processing. Journal of Food Science, 67(1), 409415. https://doi.org/10.1111/j.13652621.2002.tb11419.x

Gorinstein, S., Poovarodom, S., Leontowicz, H., Leontowicz, M., Namiesnik, J., Vearasilp, S., Haruenkit, R., Ruamsuke, P., Katrich, E. and Tashma, Z. (2011). Antioxidant properties and bioactive constituents of some rare exotic Thai fruits and comparison with conventional fruits: in vitro and in vivo studies. Food Research International, 44(7), 2222-2232. https://doi.org/10.1016/

j.foodres.2010.10.009

Hagerman, A.E. and Austin, P.J. (1986). Continuous spectrophotometric assay for plant pectin methyl esterase. Journal of Agricultural and Food Chemistry, 34(3), 440-444. https://doi.org/10.1021/ jf00069a015

Hendrickx, M., Ludikhuyze, L., Van den Broeck, I. and Weemaes, C. (1998). Effects of high-pressure on enzymes related to food quality. Trends in Food Science and Technology, 9(5), 197-203. https:// doi.org/10.1016/S0924-2244(98)00039-9

Ho, L.-H. and Bhat, R. (2015). Exploring the potential nutraceutical values of durian (Durio zibethinus L.)- 
An exotic tropical fruit. Food Chemistry, 168, 80-89. https://doi.org/10.1016/j.foodchem.2014.07.020

Huang, W., Bi, X., Zhang, X., Liao, X., Hu, X. and Wu, J. (2013). Comparative study of enzymes, phenolics, carotenoids and color of apricot nectars treated by high hydrostatic pressure and high temperature short time. Innovative Food Science and Emerging Technologies, 18, 74-82. https://doi.org/10.1016/ j.ifset.2013.01.001

Jurick, W., Vico, I., Whitaker, B., Gaskins, V. and Janisiewicz, W. (2012). Application of the 2Cyanocetamide Method for Spectrophotometric Assay of Cellulase Enzyme Activity. Plant Pathology Journal, 11, 38-42. https:// doi.org/10.3923/ppj.2012.38.41

Ketsa, S. and Pangkool, S. (1994). The effect of humidity on ripening of durians. Postharvest Biology and Technology, 4(1-2), 159-165. https:// doi.org/10.1016/0925-5214(94)90017-5

Landl, A., Abadias, M., Sárraga, C., Viñas, I. and Picouet, P.A. (2010). Effect of high-pressure processing on the quality of acidified Granny Smith apple purée product. Innovative Food Science and Emerging Technologies, 11(4), 557-564. https:// doi.org/10.1016/j.ifset.2010.09.001

Liu, F., Li, R., Wang, Y., Bi, X. and Liao, X. (2014). Effects of high hydrostatic pressure and hightemperature short-time on mango nectars: Changes in microorganisms, acid invertase, 5hydroxymethylfurfural, sugars, viscosity, and cloud. Innovative Food Science and Emerging Technologies, 22, 22-30. https://doi.org/10.1016/ j.ifset.2013.11.014

Liu, S., Xu, Q., Li, X., Wang, Y., Zhu, J., Ning, C., Chang, X. and Meng, X., (2016). Effects of high hydrostatic pressure on physicochemical properties, enzymes activity, and antioxidant capacities of anthocyanins extracts of wild Lonicera caerulea berry. Innovative Food Science and Emerging Technologies, 36, 48-58. https://doi.org/10.1016/ j.ifset.2016.06.001

Matser, A.M., Krebbers, B., van den Berg, R.W. and Bartels, P.V. (2004). Advantages of high-pressure sterilisation on quality of food products. Trends in Food Science and Technology, 15(2), 79-85. https:// doi.org/10.1016/j.tifs.2003.08.005

Park, S.Y., Ha, J.-H., Kim, S.H. and Ha, S.-D. (2017). Effects of high hydrostatic pressure on the inactivation of norovirus and quality of cabbage Kimchi. Food Control, 81, 40-45. https:// doi.org/10.1016/j.foodcont.2017.05.033
Pascua, O. and Cantila, M. (1992). Maturity indices of durian (durio zibethinus murray). Philippine Journal of Crop Science, 17(3), 119-124.

Pauziah, M., Hamilah, H., Tarmizi, S. and Masdek, N. (1992). Quality evaluation of hand harvested fruit of durian clone D24, Proceedings of the National IRPA Intensification of Research in Priority Areas Seminar Agricultural Sector, pp. 634-635.

Queirós, R.P., Santos, M.D., Fidalgo, L.G., Mota, M.J., Lopes, R.P., Inácio, R.S., Delgadillo, I. and Saraiva, J.A. (2014). Hyperbaric storage of melon juice at and above room temperature and comparison with storage at atmospheric pressure and refrigeration. Food Chemistry, 147, 209-214. https:// doi.org/10.1016/j.foodchem.2013.09.124

Roessler, E., Pangborn, R., Sidel, J. and Stone, H. (1978). Expanded statistical tables for estimating significance in paired-preference, paireddifference, duo-trio and triangle tests. Journal of Food Science, 43(3), 940-943. https:// doi.org/10.1111/j.1365-2621.1978.tb02458.x

Terefe, N.S., Gamage, M., Vilkhu, K., Simons, L., Mawson, R. and Versteeg, C. (2009). The kinetics of inactivation of pectin methylesterase and polygalacturonase in tomato juice by thermosonication. Food Chemistry, 117(1), 20-27. https://doi.org/10.1016/j.foodchem.2009.03.067

Voon, Y., Hamid, N.S.A., Rusul, G., Osman, A. and Quek, S. (2006). Physicochemical, microbial and sensory changes of minimally processed durian (Durio zibethinus cv. D24) during storage at 4 and 28 C. Postharvest Biology and Technology, 42(2), 168-175.

https://doi.org/10.1016/ j.postharvbio.2006.06.006

Wasnin, R.M., Karim, M.S.A. and Ghazali, H.M. (2014). Effect of temperature-controlled fermentation on physico-chemical properties and lactic acid bacterial count of durian (Durio zibethinus Murr.) pulp. Journal of Food Science and Technology, 51(11), 2977-2989. https://doi.org/10.1007/s13197-012-0869 $-7$ 